\title{
The Dynamic Linkage between Income, Energy Consumption, Urbanization and Carbon Emissions in Pakistan
}

\author{
Aliya Shaheen ${ }^{1 *}$, Jinyong Sheng ${ }^{1}$, Sadia Arshad ${ }^{2}$, Shafaq Salam¹, Muhammad Hafeez \\ ${ }^{1}$ Beijing University of Posts and Telecommunications, Beijing, China \\ ${ }^{2}$ COMSATS University Islamabad, Lahore Campus, Lahore, Pakistan
}

Received: 14 July 2018

Accepted: 10 September 2018

\begin{abstract}
This paper spotlights whether gross domestic product (GDP), energy consumption and urbanization affect Carbon dioxide $\left(\mathrm{CO}_{2}\right)$ emissions covering the time span 1972-2014 in Pakistan. The empirical estimates of autoregressive distributed lag (ARDL) affirmed that energy consumption and GDP are the main drivers of the pollutant environment in Pakistan, and also quantitatively determine the definite impact percentage of each dynamic force in Pakistan. Specifically, the empirical findings determine that in the long run, energy consumption and GDP intensify $\mathrm{CO}_{2}$ emissions showing significant impact; however, industrialization and urbanization are found to be insignificant. Based on empirical findings, this suggests that the constricting economic gap implementation between urban and rural areas, amendments to the energy erection and mechanical novelty will offer a treasured reference for Pakistan in exertions to diminish carbon emissions.
\end{abstract}

Keywords: environment, economic growth, industrialization

\section{Introduction}

Environmental snags generate an instantaneous threat to human welfare and lead to death. Climate change and environmental devastation are further augmented, which lead to natural disasters [1]. Starting from the agricultural age towards the industrial age, transformed man-made activities seriously affected the natural environment. The negative implications of man-made activities lead to the total destruction of the natural environment. In 1986, the Greenhouse effect

*e-mail: aliya.shaheen786@yahoo.com was identified by Svante Ahrrenius [2]. In the modern era, there is a serious global warming consensus due to the rapid increase in GHGs. Global warming (climate change) is one of the most serious problems, caused by the emission of combustion of oil, coal and natural gas (fossil fuels), resulting in the quick rise in greenhouse gases - especially the $\mathrm{CO}_{2}$ that is deteriorating the environment.

Nowadays, environment degradation is a problem that falls under mutual but distinguished duties because its preys are not inevitably only those who are accountable for eliciting the problem by excessive greenhouse emissions since the Industrial Revolution. Pakistan is a firm smash by climate change. Nonetheless, 
it gives very petite to the overall greenhouse gas (GHG) emissions. Pakistan ranks 135th with respect to per capita GHG emissions all over the world. The Global climate risk index (GCRI) of German watch 2012 classified Pakistan as eighth among in excess of 180 states of the world. Previously, in 2010, GCRI had considered it first. Pakistan is currently a trivial GHG emitter $(0.8 \%$ of global GHG). Urban air pollution of Pakistan is among the utmost austere in the world and it engenders substantial impairment to the economy and human health, in 2005 approximately more than 22,600 adult deaths in some way were caused by urban air pollution. More than 80,000 hospital admittances per year were caused by only outdoor air pollution; and almost five million cases of lower respiratory diseases in children under the age of 5 and nearly 8,000 cases of chronic bronchitis [3].

Economic growth is a progression of industrialization and urbanization, for which people transform their mode of work from agricultural to industrial and also their way of living from rural to urban. This transformation modernizes the way of living, but also effects the environment by emitting GHGs - especially $\mathrm{CO}_{2}$. Particularly in urban areas, Pakistan faces critical environmental complications. These could easily put in danger sustainable development and incessant economic growth in Pakistan [4]. Apart from the growing economy, it would also be a prerequisite to encourage maintainable development in cities of Pakistan in order to improve the quality of life and mend the urban environment to increase economic performance. Urbanization is also resulting in more emissions of $\mathrm{CO}_{2}$. However, the increased number of people at one place means more use of fossil fuels that will emit more $\mathrm{CO}_{2}$ into the air [1]. Henceforth, by reviewing the research, we found that the main contributors of $\mathrm{CO}_{2}$ emissions remained energy intensity, trade, population, technology, urbanization, economic growth, industrialization and affluence [5]. According to the work of [6] and [7], the state of a country is a principal actor in the depletion of the environment. Non-high income countries with varying stages of improvement, including lower center and upper center salary nations, may differ in their effects of decaying condition, particularly $\mathrm{CO}_{2}$ emanation and in creating arrangements because of them accordingly.

Although the subject of this study is an extensively evaluated area in the educational and research arena, the relationship between economic growth and urbanization has received continuous attention from policy makers and in academic circles. Findings of [8] provide evidence that the impact of urbanization level on carbon emissions differs with varied growth phases. Taking into concern regional urbanization differences, in [9] the impact of urbanization level on carbon emanations examined for China. They build up that this impact contrasts through districts. The STIRPAT model was utilized to recognize impact factors on carbon emanations for China [10]. They revealed that together with GDP per capita, urbanization, industrialization and populace scale could induce the heightening of carbon emissions. Related outcomes could be attained from the experimental works of [11] for Beijing City, and [12] for Guangdong Province. Henceforth in Pakistan, sufficient research has not been done according to the erratic state to examine the impact of energy consumption, industrialization, and economic growth, along with consideration of urbanization on environmental degradation. Yet, there is still a momentous gap in the literature. Prior research studies majorly concentrated on energy demand, trade openness, economic development, renewable energy, non-renewable energy, and EKC framework [13-17]. Whereas some studies further added EKC hypothesis with various air pollutants [18] and a small number of studies have focused on energy intensity. A mutual feature of most of the studies is that they have concentrated on developed economies, whereas only very limited have focused on developing countries like Pakistan. In [2], the effects of urbanization and genuine financial advancement on $\mathrm{CO}_{2}$ emissions in non-high pay nations investigated in view of the broadened STIRPAT model.

In the last decade (2001-2010) a number of developing countries have experienced exceptional instantaneous growth in both urbanization and GDP per capita. Since the 1970s, rising nations have encountered quick-paced urbanization and industrialization, actuated by quick financial development. These procedures are likewise escorted by fast accelerations in fossil vitality demand and $\mathrm{CO}_{2}$ emissions. The study contributes to existing literature as follows: Firstly, the current study follows the successive observed illustrations from the prevailing literature and incorporated a few more variables in the $\mathrm{CO}_{2}$ framework in the context of Pakistan for vigorous policy inference. Secondly, the prior studies added FDI inflows [19-20] financial development indicators [17,21] through varied economic settings, though as per authors information, none of the study added urbanization, industrialization, energy consumption with economic growth to investigate the impact on $\mathrm{CO}_{2}$ emissions in a large panel settings in the context of Pakistan. Lastly, the relationship between carbon emissions and urbanization is a less explored area in Pakistan, and is mainly exercised on China [22] and the Chinese economy [23-24], Turkey [25], Japan [26], ASEAN countries [27], developed countries [28] and Nigeria [1]. These differences noticeably specify the requirement of the cooperating environmental model in Pakistan, where the key causes of environmental degradation can be detect and offer credible environmental solutions. The present study concentrated on these causes and projected supportable policies.

The environment affects every sector of the country, though Pakistan is not actually a developed country, yet environmental pollution is going to become an issue, and for that reason a sturdy national policy is very critical to chaperon climate change adaptation. Thus, in order to overcome the serious challenges of pollution 
of air, water and land, our policy implication is that it is very important to ensure sufficient social sector investments, particularly for the environment. Therefore, this study is an augment in the literature by examining the impact of economic growth and urbanization on environmental degradation of Pakistan. It will provide a comprehensive economic insinuation for the upgrading of environmental criterions. In our study, we accomplish the ARDL-bound testing approach to explore the linkage between industrialization, energy consumption, economic growth, urbanization, and carbon emissions for Pakistan, and to find out the potential causes of contaminated environment and provide solution for the hidden issues of fumes.

\section{Brief Literature Review}

Economic growth and industrialization altered the status of the country from being less developed to developed; however, this economic growth and industrialization brings some serious issues like deterioration of the environment by the emission of harmful gases - especially $\mathrm{CO}_{2}$. The existing literature pointed out in different countries cases of environmental degradation by the emission of $\mathrm{CO}_{2}$, trade, urbanization and level of income [5, 8, 17, 29-32]. However, the rate of depletion of environment for all countries is not the same. For European Union countries, outcomes of the study [33] specified that populace progression is certainly associated with the upsurge of carbon emissions, and that environmental impressions are slighter in comparatively progressive member countries. In [26] a study carried out in Japan explained that increased use of energy means more environmental pollution; however, urbanization, foreign trade and economic growth do not affect the environment. A study was carried out in Nigeria using a multivariate vector error correction model. The results pointed out increased economic growth in more energy consumption and an increased emission of $\mathrm{CO}_{2}$ in the long run [34], while [35] pointed out that $8.4 \%$ of $\mathrm{CO}_{2}$ emissions is caused by a $10 \%$ increase in GDP; moreover, $10 \%$ energy intensity (EI) causes a $2.4 \%$ increase in the emission of $\mathrm{CO}_{2}$. A panel co-integration test was applied on emerging and frontier Asian (EFA) markets from the period 1960-2015 and their results confirmed the EKC hypothesis with the nearness of the transformed U-shaped connection between financial development and $\mathrm{CO}_{2}$ discharge, but be that as it may, populace development negatively affects $\mathrm{CO}_{2}$ emanation in EFA [36]. Energy also caused an increase in $\mathrm{CO}_{2}$ emissions such as oil, gas and electricity is expansively consumed in many sectors such as transportation, industry and services. In [2], findings indicated that real economic development does not cause increased $\mathrm{CO}_{2}$ emissions in upper and lower middle income countries; however, urbanization caused a small increase in $\mathrm{CO}_{2}$ emissions. Voluminous studies in different countries of the world extensively discussed the connection of the environment with energy consumption and economic growth. Some researchers have found that the impact on $\mathrm{CO}_{2}$ emissions differs with the level of development of a country. Applying the STIRPAT model across 99 countries [8] pointed out that urbanization is emitting more $\mathrm{CO}_{2}$ in middle and high income countries. [7] applied the panel data set model to 69 countries from low, middle and high income groups and revealed that GDP, trade openness and energy consumption accelerates the emission of $\mathrm{CO}_{2}$. However, urbanization has a negative effect on all countries. [37] uncovered that in the low remuneration group, urbanization expands $\mathrm{CO}_{2}$ discharge, in the center/low pay and high remuneration groups, industrialization builds $\mathrm{CO}_{2}$ outflows, while urbanization fundamentally expands $\mathrm{CO}_{2}$ emanations, and for the center/high remuneration groups, urbanization does not altogether but rather hinders the development of outflows, while industrialization was found to have an immaterial impact on $\mathrm{CO}_{2}$ emissions and also increase emissions except for the high income group. Overall, there is a unidirectional relationship among population growth and $\mathrm{CO}_{2}$ emissions. In [21] researchers argued that the Industrial Revolution also thrust urbanization and industrialization as the main ways to monetary and social redesigning. Alternately, these methods invigorate the quick development of petroleum derivative ingestion and deliver groundbreaking measures of carbon dioxide $\left(\mathrm{CO}_{2}\right)$ and other ozone-depleting substance (GHG) emanations. There are a lot of studies for carbon emissions, including indoor and outdoor - especially urban cities and parks. It shows that PM2.5 affected human health. Solar radiation in urban areas also affects human health. The plants indoor are affected by solar radiation. This leads to climate change in the environment as well as forest, coastal, and urban areas [38-46]. A recent study shows that carbon emissions affect thermal comfort and lead to climate change problems [56-60]. Thus, it demands natural areas and coastal areas [47-51].

\section{Material and Methods}

\section{Data and Sources}

On the basis of availability of data, this study was used data for the selected time period 1972-2014. Monetary growth is estimated as GDP per capita (constant 2010 US\$), environmental degradation computed as $\mathrm{CO}_{2}$ emissions (metric tons per capita), urbanization as urban populace (percentage of aggregate), energy consumption is estimated as vitality utilized ( $\mathrm{kg}$ of oil equivalent per capita), industry value added (constant 2010 US\$) used to measure industrialization. Data is collected from a database of the World Bank known as the world development indicator (WDI). The recent patterns of concern variable are illustrated in Fig. 1. 

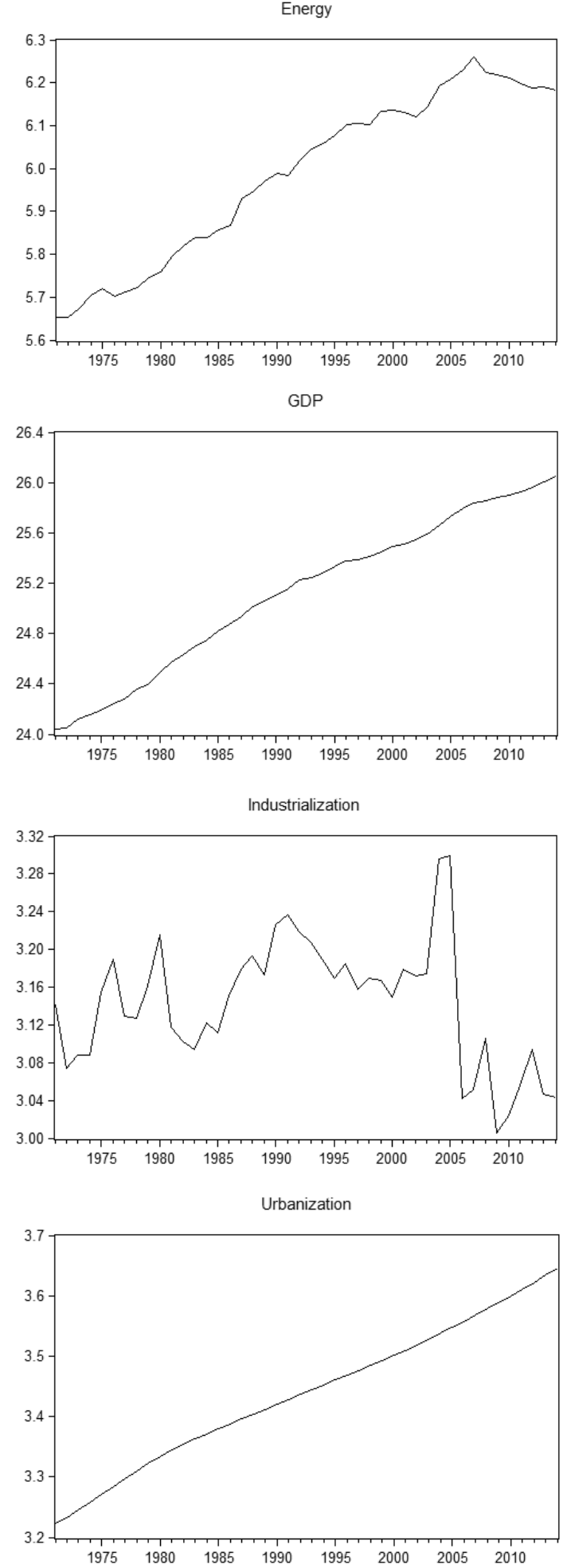

Fig. 1. Trend of the variables.

\section{Econometric Model and Background}

Urbanization in growth equation to assess the abovediscussed relationship incorporated in [52]. Urbanization is an important determinant of environmental quality and in [31] expressed the dynamic link between urban population and $\mathrm{CO}_{2}$ emissions. Most past research determined that urbanization and industrialization upsurge vitality utilization and carbon outflows [5]. In [29], researchers organized a negative impact of urbanization level reporting in real time contamination file in China for the length of 2003-2010. Urbanization is usually meant by the extent of the proportion of urban-to-total population [28, 53-55]. Consumption of energy is among the core factor of $\mathrm{CO}_{2}$ emissions, which is straightaway interrelated to income level. Further ongoing writing procured carbon outflows as an intermediary pointer of environmental quality based on the STIRPAT model [17]. Conferring in the study that industrialization and urbanization would prompt financial development and heightening of GDP per capita, by implication prompting escalations of $\mathrm{CO}_{2}$ outflows [2]. Specifically in the present study, we select industrialization, economic growth, urbanization and energy consumption as explanatory variables to explore their impact on carbon emissions in the context of Pakistan.

Accordingly, we have incorporated these indicators in our model based on theoretical framework in Fig. 2 and we can write the functional form of $\mathrm{CO}_{2}$ emissions as follows see Fig. 2:

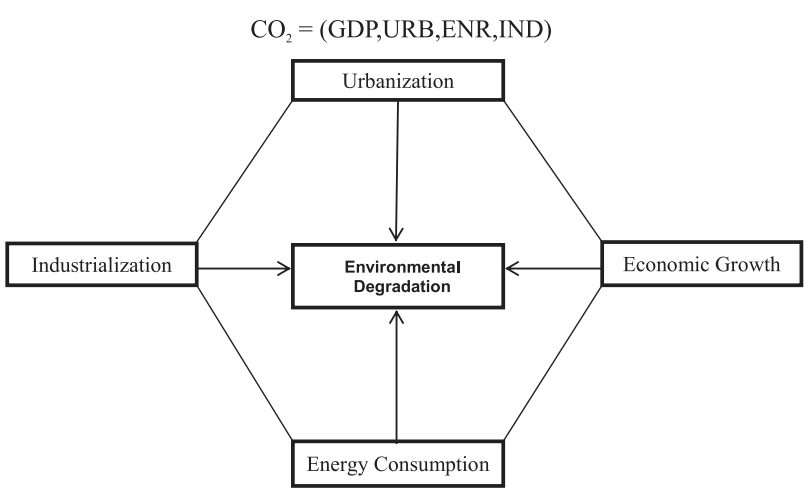

Fig. 2. Theoretical framework

...where:

$\mathrm{CO}_{2}=$ Carbon dioxide emissions

GDP $=$ Real GDP (Economic Growth)

$\mathrm{URB}=$ Urbanization

$\mathrm{ENR}=$ Energy consumption

$\mathrm{IND}=$ Industry value added

Taking logs, the linearized model is given by:

$$
\begin{gathered}
\ln \mathrm{CO} 2=\alpha+\beta_{1} \ln G D P+\beta_{2} \ln U R B+ \\
\beta_{3} \ln E N R+\beta_{4} \ln I N D
\end{gathered}
$$

...where:

$\ln =$ Natural logarithm

$\alpha=$ Intercept

$\beta_{1}=$ Elasticity of $\mathrm{CO}_{2}$ emissions with respect to economic growth

$\beta_{2}=$ Elasticity of $\mathrm{CO}_{2}$ emissions with respect to urbanization

$\beta_{3}=$ Elasticity of $\mathrm{CO}_{2}$ emissions with respect to energy consumption 
$\beta_{4}=$ Elasticity of $\mathrm{CO}_{2}$ emissions with respect to industrialization

Based on the above equation we continue to figure our autoregressive distributed lags (ARDL) that will be assessed, keeping in mind that the end goal is to discover the connections among the factors under scrutiny as appeared in the following equation:

$$
\begin{gathered}
\Delta \ln C O 2_{t}=\alpha+\beta_{1} \ln C O 2_{t-1}+\beta_{2} \ln G D P_{t-1}+ \\
\beta_{3} \ln U R B_{t-1}+\beta_{4} \ln E N R_{t-1}+\beta_{5} \ln I N D_{t-1}+ \\
\sum_{i=1}^{p_{1}} \gamma_{i} \Delta \ln C O 2_{t-i}+\sum_{j=1}^{p_{2}} \omega_{j} \Delta \ln G D P_{t-j}+ \\
\sum_{k=1}^{p_{3}} \delta_{k} \Delta \ln U R B_{t-k}+\sum_{l=1}^{p_{4}} \varphi_{l} \Delta \ln E N R_{t-l}+ \\
\sum_{m=1}^{p_{5}} \theta_{m} \Delta \ln I N D_{t-m}+\mu_{t}
\end{gathered}
$$

... where $\mu_{\mathrm{t}}$ is a random error term and subscript $\mathrm{t}$ indicates time period. We utilize the following Eq., keeping in mind that the end goal is to test the longrun coefficients of ARDL:

$$
\begin{gathered}
\ln C O 2_{t}=\sum_{i=1}^{q_{1}} \gamma_{i} \ln C O 2_{t-i}+\sum_{j=1}^{q_{2}} \omega_{j} \ln G D P_{t-j}+ \\
\sum_{k=1}^{q_{3}} \delta_{k} \ln U R B_{t-k}+\sum_{l=1}^{q_{4}} \varphi_{l} \ln E N R_{t-l}+ \\
\sum_{m=1}^{q_{5}} \theta_{m} \ln I N D_{t-m}+\mu_{t}
\end{gathered}
$$

To choose lag length of the model, Schwarz Bayesian Criterion (SBC) is picked and applied error correction mode with a view to decide short-run elements of the factors:

$$
\begin{gathered}
\Delta \ln C O 2_{t}=\sum_{i=1}^{r_{1}} \gamma_{i} \Delta \ln C O 2_{t-i}+ \\
\sum_{j=1}^{r_{2}} \omega_{j} \Delta \ln G D P_{t-j}+\sum_{k=1}^{r_{3}} \delta_{k} \Delta \ln U R B_{t-k}+ \\
\sum_{l=1}^{r_{4}} \varphi_{l} \Delta \ln E N R_{t-l}+\sum_{m=1}^{r_{5}} \theta_{m} \Delta \ln I N D_{t-m}+ \\
\text { vecm } e_{t-1}+\mu_{t}
\end{gathered}
$$

\section{Results and Discussion}

In descriptive statistics, the probability value of Jarque-Bera for all variables is more than 0.05 , i.e., $\operatorname{lnCO} 20.15, \operatorname{lnIND} 0.93, \operatorname{lnGDP} 0.22, \operatorname{lnURB} 0.40$, lnENR 0.12 respectively; which indicates normal residuals.

\section{ARDL Bounds Testing}

For the ARDL bounds testing approach to cointegration, the prime step is to investigate the unit root properties of the variables to proceed. We confirm that none of the variables are assimilated at I(2). In order to get meaningful results from data we have applied the ADF test by Dickey and Fuller. Studies have been carried out on the environment by using the ARDL framework, for instance in China by [22], [56] in Turkey and [1] in Nigeria.

The time period that our data set contains is properly elongated (42 years); it is expected that a unit root process will be followed by macroeconomic variables. We apply these tests to assured that no series go beyond I(1) order of integration. For circumventing specious regression analysis, the stationary of time series data is essential, as it is incredible to get consistent results and project with nonstationary series. Table 2 indicates the outcomes of unit root tests. All variables are tested which propose that maximum of the variables under

Table 1. Statistical analysis of variables.

\begin{tabular}{|c|c|c|c|c|c|}
\hline & \multicolumn{1}{|c|}{$\operatorname{lnO}_{2}$} & $\operatorname{lnIND}$ & $\operatorname{lnGDP}$ & $\operatorname{lnURB}$ & $\operatorname{lnENR}$ \\
\hline Mean & -0.504988 & 3.142711 & 25.12309 & 3.438687 & 5.985650 \\
\hline Median & -0.424809 & 3.152676 & 25.23607 & 3.440506 & 6.032609 \\
\hline Maximum & -0.009011 & 3.299575 & 26.05201 & 3.645528 & 6.261040 \\
\hline Minimum & -1.175706 & 3.005558 & 24.04145 & 3.222230 & 5.653114 \\
\hline Std. Dev. & 0.372969 & 0.067375 & 0.621976 & 0.118686 & 0.197046 \\
\hline Skewness & -0.386092 & 0.073708 & -0.262221 & -0.063735 & -0.319321 \\
\hline Kurtosis & 1.796575 & 2.780541 & 1.835441 & 2.009552 & 1.639328 \\
\hline Jarque-Bera & 3.748250 & 0.128139 & 2.990604 & 1.828267 & 4.142036 \\
\hline Probability & 0.153489 & 0.937940 & 0.224181 & 0.400864 & 0.126057 \\
\hline Sum & -22.21946 & 138.2793 & 1105.416 & 151.3022 & 263.3686 \\
\hline Sum Sq. Dev. & 5.981538 & 0.195195 & 16.63474 & 0.605716 & 1.669559 \\
\hline Observations & 44 & 44 & 44 & 44 & 44 \\
\hline
\end{tabular}


Table 2. Results of Unit of root Test (ADF Test).

\begin{tabular}{|c|c|c|c|c|c|c|c|}
\hline \multirow{2}{*}{\multicolumn{2}{|c|}{ Variables }} & \multicolumn{3}{|c|}{ Level } & \multicolumn{3}{|c|}{ First Difference } \\
\hline & & \multirow{2}{*}{$\begin{array}{c}\mathrm{C} \\
0.3385 \\
1.8796\end{array}$} & \multirow{2}{*}{$\begin{array}{c}\text { C\&T } \\
0.9983 \\
0.3390\end{array}$} & \multirow{2}{*}{$\begin{array}{c}\text { None } \\
1.0000 \\
4.2127\end{array}$} & \multirow{2}{*}{$\begin{array}{c}C \\
0.0001 \\
5.1603\end{array}$} & \multirow{2}{*}{$\begin{array}{c}\text { C\&T } \\
0.0001 \\
5.6972\end{array}$} & \multirow{2}{*}{$\begin{array}{c}\text { None } \\
0.0002 \\
3.9391\end{array}$} \\
\hline $\operatorname{lnENR}$ & $\begin{array}{l}\text { P-value } \\
\text { t-value }\end{array}$ & & & & & & \\
\hline $\operatorname{lnGDP}$ & & $\begin{array}{l}0.1258 \\
2.4869\end{array}$ & $\begin{array}{l}0.9290 \\
1.0272\end{array}$ & $\begin{array}{l}1.0000 \\
4.4166\end{array}$ & $\begin{array}{l}0.0002 \\
4.9160\end{array}$ & $\begin{array}{l}0.0002 \\
5.6732\end{array}$ & $\begin{array}{l}0.1485 \\
1.3979\end{array}$ \\
\hline $\operatorname{lnIND}$ & & $\begin{array}{l}0.0686 \\
2.7865\end{array}$ & $\begin{array}{l}0.1844 \\
2.8622\end{array}$ & $\begin{array}{l}0.5961 \\
0.2331\end{array}$ & $\begin{array}{l}0.0000 \\
7.3650\end{array}$ & $\begin{array}{l}0.0000 \\
7.4677\end{array}$ & $\begin{array}{l}0.0000 \\
7.4543\end{array}$ \\
\hline $\ln U R B$ & & $\begin{array}{l}0.9991 \\
1.5251\end{array}$ & $\begin{array}{l}0.0016 \\
4.8643\end{array}$ & $\begin{array}{l}0.9930 \\
2.2407\end{array}$ & $\begin{array}{l}0.2390 \\
2.1177\end{array}$ & $\begin{array}{l}0.0000 \\
7.2862\end{array}$ & $\begin{array}{l}0.3858 \\
0.7488\end{array}$ \\
\hline $\ln \mathrm{CO}_{2}$ & & $\begin{array}{c}0.8559 \\
-0.6180\end{array}$ & $\begin{array}{c}0.7128 \\
-1.7465\end{array}$ & $\begin{array}{l}0.0193 \\
-2.3604\end{array}$ & $\begin{array}{c}0.0005 \\
-4.6819\end{array}$ & $\begin{array}{c}0.0000 \\
-10.2960\end{array}$ & $\begin{array}{c}0.0588 \\
-1.8737\end{array}$ \\
\hline
\end{tabular}

*Level of statistical significance for ADF tests with constant (c) and with constant \& trend (C\&T) is 5\%.

Table 3. Autoregressive distributed lag estimates.

\begin{tabular}{|c|c|c|c|c|}
\hline F-statistic 95\% & Lower Bound 95\% & Upper Bound 90\% & Lower Bound 90\% & Upper Bound \\
\hline 15.6675 & 3.9131 & 5.1434 & 3.2946 & 4.4152 \\
\hline W-statistic 95\% & Lower Bound 95\% & Upper Bound 90\% & Lower Bound 90\% & Upper Bound \\
\hline 78.3374 & 19.5654 & 25.7168 & 16.4729 & 22.0761 \\
\hline
\end{tabular}

$\operatorname{ARDL}(1,0,0,1,0)$

concern are stationary at first difference and some are at level. Energy, GDP, industrialization and $\mathrm{CO}_{2}$ are stationary at first difference, hence they are $\mathrm{I}(1)$ variables and we reject the null hypothesis. However, urbanization is integrated of order at $\mathrm{I}(0)$ with constant and trend. Due to these variegated orders of integration, rather than the traditional panel co-integration test panel the ARDL approach is applicable.

F-statistic (15.66) is higher than the upper bound, and the decision rule as proposed in [57] is that if the estimated F-test value is greater than the upper bound critical value, null hypothesis will be rejected, hence there is co-integration among the set of $(\mathrm{I}(0)$ and $\mathrm{I}(1)$ ) variables and we undertake that there can be at the minimum short run or long run association between variables.

Table 4. Estimated long run coefficients using the ARDL approach.

\begin{tabular}{|c|c|c|}
\hline Regressor & Coefficient & T-Ratio (P value) \\
\hline $\operatorname{lnGDP}$ & 0.4124 & $2.7183[.010]$ \\
\hline $\operatorname{lnURB}$ & 1.9820 & $1.6984[.098]$ \\
\hline $\operatorname{lnIND}$ & -.09478 & $1.1898[.242]$ \\
\hline $\operatorname{lnENR}$ & 1.4075 & $5.3071[.000]$ \\
\hline INPT & -25.1326 & $-9.8250[.000]$ \\
\hline TREND & -0.0301 & $-3.4994[.001]$ \\
\hline
\end{tabular}

Table 4 shows the long run estimates, GDP, and ENR showing significant and positive results. A $1 \%$ increase in economic growth (GDP) raises $\mathrm{CO}_{2}$ emissions by 0.412 , and a $1 \%$ increase in energy consumption escalates $\mathrm{CO}_{2}$ emissions by 1.41. IND is negative and insignificant, while URB is positive but insignificant. These results are in line with [58], who also confirm that urbanization is inconsequential in increasing emissions. However, it significantly increases energy consumption. Henceforth variables are co-integrating as we have seen from the F-Stat in Table 3. Most of the variables are affecting each other in the long run.

In short run constituents, furthermost important is ecm(-1) and results show that it is -0.85 (near to -1 ) and also significant $(0.00)$ then it is ideal, ensuring that there is conjunction in the model that circuitously shows that there is a substantial long-run relationship.

To evaluate the sturdiness of the empirical model, we used four provided diagnostics. Foremost is serial correlation, which is insignificant as per $\mathrm{F}$ version and $\mathrm{LM}$ version. Equally, the functional form is trivial, normality is also inconsequential and heteroscedasticity is insignificant too, according to both the F and LM versions. Consequently, we can take up that there is no auto-correlation and henceforth there is no outward issue with this model.

We performed CUSUM and CUSUMSQ tests to check for the stability of the long and short run estimates. In Figs 3 and 4, estimated lines do not cross the two critical lines. This means that there is 
Table 5. Error correction representation for the selected ARDL model.

\begin{tabular}{|c|c|c|c|}
\hline Regressor & Coefficient & Standard Error & T-Ratio (Prob) \\
\hline $\mathrm{d} \operatorname{lnGDP}$ & 0.3514 & 0.1470 & $2.3905[.022]$ \\
\hline dlnURB & 1.6887 & 0.9026 & $1.8708[.070]$ \\
\hline dlnIND & 0.0627 & 0.0643 & $.97484[.336]$ \\
\hline dlnENR & 1.1992 & 0.1878 & $6.3838[.000]$ \\
\hline dTREND & -0.0257 & 0.0060 & $-4.2628[.000]$ \\
\hline ecm $(-1)$ & -0.8520 & 0.0794 & $-10.7175[.000]$ \\
\hline \multicolumn{2}{|c|}{ R-Squared } & \multicolumn{2}{|c|}{.86952} \\
\hline \multicolumn{2}{|c|}{ Residual Sum of Squares } & \multicolumn{2}{|c|}{.014724} \\
\hline \multicolumn{2}{|c|}{ DW-statistic } & \multicolumn{2}{|c|}{2.0057} \\
\hline \multicolumn{2}{|c|}{ F-Stat. } & \multicolumn{2}{|c|}{$\mathrm{F}(6,36) 38.8719[.000]$} \\
\hline
\end{tabular}

In short run constituents, furthermost important is ecm(-1) and results show that it is -0.85 (near to -1$)$ and also significant $(0.00)$ then it is ideal, ensuring that there is conjunction in the model that circuitously shows that there is a substantial long-run relationship.

Table 6. Diagnostic tests results.

\begin{tabular}{|c|c|c|}
\hline Test statistics & LM version & F-version \\
\hline A: Serial Correlation & CHSQ $(1)=.056898[.811] \mathrm{F}(1,34)$ & $=.045049[.833]$ \\
\hline B: Functional Form & CHSQ $(1)=.031441[.859] \mathrm{F}(1,34)$ & N/A \\
\hline C: Normality & $\mathrm{CHSQ}(2)=.12717[.938]$ & $=.93585[.339]$ \\
\hline D: Heteroscedasticity & $\mathrm{CHSQ}(1)=.95960[.327] \mathrm{F}(1,41)$ & $.876]$ \\
\hline
\end{tabular}

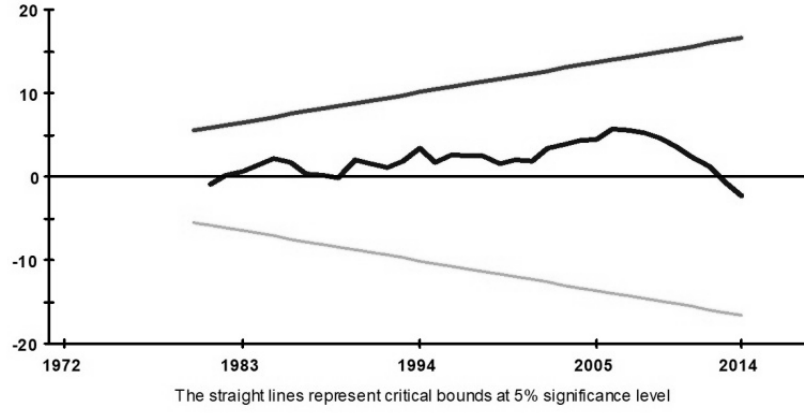

Fig. 3. Plot of Cumulative sum of recursive residuals.

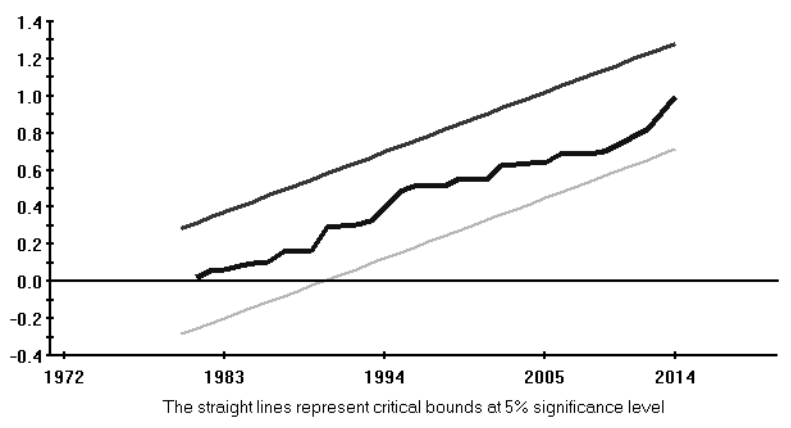

Fig. 4. Plot of cumulative sum of squares of recursive residuals. no concern of recursive residuals in terms of mean (in first CUSUM chart) and in terms of variance (in second CUSUMSQ chart).

\section{Conclusion}

We are certain that these empirical findings not only augment the current literature, but also are worth larger thoughtfulness from developing countries. The significant inference of the findings is that countries should observe different strategies to endorse economic growth, industrialization, energy consumption and urbanization according to their stage of development in order to protect the environment and decrease emissions. The swift development of urbanization and energy use has appealed much thoughtfulness from policy makers and educational groups. Our empirical work takes a renewed look at the association between GDP, industrialization, energy consumption, urbanization and carbon emissions in Pakistan, using yearly data for the duration of 1972-2014. To summarize, findings of the study showing that GDP (economic growth) and energy consumption have significant and positive impact on $\mathrm{CO}_{2}$ emissions and these findings reconfirm the results of [59], and our results are also consistent with findings of [25] and [1]. Nevertheless, our findings 
are in line with [27], who find that there is evidence for the existence of a long-term equilibrium relationship between urbanization, energy use, and carbon emissions for the ASEAN countries. Our findings of coefficients of long run result disclose that urbanization is positive, but does not have any significant impact on $\mathrm{CO}_{2}$ emissions in Pakistan, and these findings reconfirm results of [60] for developing countries and [2] for nonhigh income countries. This study also determines that there is no indication that industry has a strong positive and significant impact on $\mathrm{CO}_{2}$ emissions in Pakistan as a whole and also in the long run. Our findings contradict the common assumption that industry is a major contributor to promoting environmental pollution, results of the study of [37] reveals that industrialization increases $\mathrm{CO}_{2}$ emissions in the middle/low income and high income groups. In fact industrialization is not supporting $\mathrm{CO}_{2}$ emissions in the analysis because of its inadequate volume, as industry is not flourishing at a very advanced level in Pakistan. Thus policy inferences are recognized, policy makers and municipal organizers should accentuate coherent planning of environment management and proficient policies, with proper consideration for the environment.

The outcomes of the study specify that in Pakistan, GDP (economic growth) and energy consumption are the main sources of long-run variations in $\mathrm{CO}_{2}$ emissions. We observe that the influence of energy use on carbon emissions is larger than that of urbanization on carbon emissions in Pakistan. The causal relation of independent variables and $\mathrm{CO}_{2}$ emissions proposes that it is a prerequisite for government to control environmental degradation by implementing policies inspiring effective use of energy resources. Environmental policy planners should take it on serious grounds as in spite of lacking industrial development, Pakistan is facing a dilemma of polluted environmental issues, and they should find the crucial causes of current environmental contamination in Pakistan and to mitigate those motives. Furthermore, it is also proposed that if the government of Pakistan implements an environmental tax system, it could encourage effective consumption of energy resources and relief in lowering extravagant consumption of energy, which has no destructive significances for economic growth in the long run. One important recommendation in this respect comes up that such policies should be realized to account for the technical revolution which can have a consequence in more resourceful use of energy resources and diminish its deleterious effect of greater use of energy on the environment. In Pakistan, our empirical outcomes make assistances to the contemporary literature, and justify complete responsiveness of the government concerning reducing carbon emissions.

\section{Conflict of Interest}

The authors declare no conflict of interest.

\section{References}

1. ALI H.S., LAW S.H., ZANNAH T.I. Dynamic impact of urbanization, economic growth, energy consumption, and trade openness on $\mathrm{CO}_{2}$ emissions in Nigeria. Environmental Science and Pollution Research, 23 (12), 12435, 2016.

2. LIN S., WANG S., MARINOVA D., ZHAO D., HONG J. Impacts of urbanization and real economic development on $\mathrm{CO}_{2}$ emissions in non-high income countries: Empirical research based on the extended STIRPAT model. Journal of Cleaner Production, 166, 952, 2017.

3. WORLD BANK. Pakistan's Urban Air Pollution Off the Charts. World Bank, 2014.

4. National Report of Pakistan For HABITAT III, Government of Pakistan Ministry of Climate Change, Islamabad, Pakistan. April, 2015.

5. SHUAI C., SHEN L., JIAO L., WU Y., TAN, Y. Identifying Key Impact Factors on Carbon Emission: Evidences From Panel and Time-Series Data of 125 Countries From 1990 To 2011. Applied Energy, 187, 310, 2017.

6. DIETZ T., ROSA E. A. Effects of population and affluence on $\mathrm{CO}_{2}$ emissions. Proceedings of the National Academy of Sciences, 94 (1), 175, 1997.

7. SHARMA S.S. Determinants of Carbon Dioxide Emissions: Empirical Evidence From 69 Countries. Applied Energy, 88, 376, 2011.

8. POUMANYVONG P., KANEKO S. Does urbanization lead to less energy use and lower $\mathrm{CO}_{2}$ emissions? A cross-country analysis. Ecological Economics, 70 (2), 434, 2010.

9. ZHANG C.G., LIN Y. Panel Estimation for Urbanization, Energy Consumption and $\mathrm{CO}_{2}$ Emissions: A Regional Analysis in China. Energy Policy, 49, 488, 2012.

10. LI H., MU H., ZHANG M., LI, N. Analysis on influence factors of China's $\mathrm{CO}_{2}$ emissions based on Path-STIRPAT model. Energy Policy, 39(11), 6906, 2011.

11. WANG Z. H., YIN F.C., ZHANG Y.X., ZHANG X. An Empirical Research on the Influencing Factors of Regional $\mathrm{CO} 2$ Emissions: Evidence from Beijing City, China. Applied Energy, 100, 277, 2012.

12. WANG P., WU W.S., ZHU B.Z., WEI Y.M. Examining the Impact Factors of Energy Related $\mathrm{CO}_{2}$ Emissions Using the STIRPAT Model in Guangdong Province, China. Applied Energy, 106, 65, 2013.

13. JEBLI M. B., YOUSSEF S. B. The environmental Kuznets curve, economic growth, renewable and non-renewable energy, and trade in Tunisia. Renewable and Sustainable Energy Reviews, 47, 173, 2015.

14. OZTURK I., AL-MULALI U. Investigating the Validity of the Environmental Kuznets Curve Hypothesis in Cambodia. Ecological Indicators, 57, 324, 2015.

15. DANISH B., ZHANG B., WANG Z., WANG. Role of Renewable Energy and Non-Renewable Energy Consumption on EKC: Evidence from Pakistan. Journal of Cleaner Production, 156, 855, 2017.

16. ZAMAN K., MOEMEN M. Energy Consumption, Carbon Dioxide Emissions and Economic Development: Evaluating Alternative and Plausible Environmental Hypothesis for Sustainable Growth. Renewable and Sustainable Energy Reviews, 74, 1119, 2017.

17. HAFEEZ M., CHUNHUI Y., STROHMAIER D., AHMED M., JIE L. Does finance affect environmental degradation: evidence from One Belt and One Road Initiative region? Environmental Science and Pollution 
Research, 25, 9579, https://doi.org/10.1007/s11356-0181317-7, 2018.

18. XU B., LIN B. How Industrialization and Urbanization Process Impacts on $\mathrm{CO}_{2}$ Emissions in China: Evidence From Nonparametric Additive Regression Models. Energy Economics, 48, 188, 2015.

19. SHAHBAZ M., NASREEN S., ABBAS F., ANIS O. Does Foreign Direct Investment Impede Environmental Quality in High, Middle, And Low-Income Countries? Energy Economics, 51, 275, 2015.

20. TANG C.F., TAN B.W. The impact of energy consumption, income and foreign direct investment on carbon dioxide emissions in Vietnam. Energy, 79, 447, 2015.

21. SALAHUDDIN M., GOW J., OZTURK I. Is the LongRun Relationship Between Economic Growth, Electricity Consumption, Carbon Dioxide Emissions and Financial Development in Gulf Cooperation Council Countries Robust? Renewable and Sustainable Energy Reviews, 51, 317, 2015.

22. LIU Y. Exploring the relationship between urbanization and energy consumption in China using ARDL (autoregressive distributed lag) and FDM (factor decomposition model). Energy, 34 (11), 1846, 2009.

23. OUYANG X., LIN B. An Analysis of the Driving Forces of Energy-Related Carbon Dioxide Emissions in China's Industrial Sector. Renewable and Sustainable Energy Reviews, 45, 838, 2015.

24. CHENG H., LI F., MAO Q. The empirical analysis on the influence of $\mathrm{CO}_{2}$ emission regulation on the export transformation of Chinese manufacturing industries. journal of coastal research, 73 (sp1), 209, 2015.

25. DESTEK M. A., OZSOY, F. N. Relationships between economic growth, energy consumption, globalization, urbanization and environmental degradation in Turkey. International Journal of Energy and Statistics, 3 (04), 1550017, 2015.

26. HOSSAIN S. An Econometric Analysis for $\mathrm{CO}_{2}$ Emissions, Energy Consumption, Economic Growth, Foreign Trade and Urbanization of Japan. Low-Carbon Economy, 3, 92, 2012.

27. WANG Y., CHEN L., KUBOTA J. The Relationship Between Urbanization, Energy Use and Carbon Emissions: Evidence From a Panel of Association of Southeast Asian Nations (ASEAN) Countries. Journal of Cleaner Production, 1, 2015

28. LIDDLE B., LUNG S. Age-structure, urbanization, and climate change in developed countries: revisiting STIRPAT for disaggregated population and consumption-related environmental impacts. Population and Environment, 31 (5), 317, 2010.

29. ZHANG X.J., ZHAO K., JENNINGS E.T. Empirical Evidence and Determinants of Region-Based Environmental Injustice in China: Does Environmental Public Service Level Make a Difference? Social Science Quarterly, 1, 1, 2016.

30. ZHOU Y., LIU Y. Does Population Have a Larger Impact on Carbon Dioxide Emissions Than Income? Evidence From a Cross-Regional Panel Analysis in China. Applied Energy, 180, 800, 2016.

31. HOSSAIN M.S. Panel estimation for $\mathrm{CO}_{2}$ emissions, energy consumption, economic growth, trade openness and urbanization of newly industrialized countries. Energy Policy, 39 (11), 6991, 2011.

32. FARHANI S., SHAHBAZ M., AROURI M.E.H. Panel analysis of $\mathrm{CO}_{2}$ emissions, GDP, energy consumption, trade openness and urbanization for MENA countries, 2013.
33. MARTÍNEZ-ZARZOSO I., BENGOCHEAMORANCHO A., MORALES-LAGE R. The impact of population on $\mathrm{CO}_{2}$ emissions: evidence from European countries. Environmental and Resource Economics, 38 (4), 497, 2007.

34. AKPAN G.E., AKPAN U.F. Electricity Consumption, Carbon Emissions and Economic Growth in Nigeria. International Journal of Energy Economic and Policy, 2 (4), 292, 2012.

35. ALAM S., FATIMA A., BUTT M.S. Sustainable development in Pakistan in the context of energy consumption demand and environmental degradation. Journal of Asian Economics, 18 (5), 825, 2007.

36. MUBEEN R., MUSHAB R. Energy Consumption to Environmental Degradation, The Growth Appetite in SAARC Nations. Journal of Renewable Energy, 111, 284, 2017.

37. LI K., LIN B. Impacts of urbanization and industrialization on energy consumption/ $/ \mathrm{CO}_{2}$ emissions: Does the level of development matter? Renewable and Sustainable Energy Reviews, 52, 1107, 2015.

38. TURKYILMAZ A., SEVIK H., CETIN M., AHMAIDA SALEH E.A. Changes in Heavy Metal Accumulation Depending on Traffic Density in Some Landscape Plants. Pol. J. Environ. Stud, 27 (5), 2277, DOI: 10.15244/ pjoes/78620, 2018.

39. KRAVKAZ KUSCU I.S., CETIN M., YIGIT N., SAVACI G., SEVIK H. Relationship between Enzyme Activity (Urease-Catalase) and Nutrient Element in Soil Use. Pol. J. Environ. Stud, 27 (5), 2107. DOI: 10.15244/pjoes/78475, 2018.

40. CETIN M., SEVIK H., YIGIT N. Climate type-related changes in the leaf micromorphological characters of certain landscape plants. Environmental Monitoring and Asessmenet. 190, 404, 2018.

41. TURKYILMAZ A., SEVIK H., \& CETIN M. The use of perennial needles as biomonitors for recently accumulated heavy metals. Landscape and Ecological Engineering, 14 (1), 115, 2018.

42. CETIN M. A Change in the Amount of $\mathrm{CO}_{2}$ at the Center of the Examination Halls: Case Study of Turkey. Studies on Ethno-Medicine, 10 (2), 146, 2016.

43. CETIN M., SEVIK H., SAAT A. Indoor Air Quality: the Samples of Safranbolu Bulak Mencilis Cave. Fresenius Environmental Bulletin, 26 (10), 5965, 2017.

44. SEVIK H., AHMAIDA E.A., CETIN M. Chapter 31: Change of the Air Quality in the Urban Open and Green Spaces: Kastamonu Sample. Ecology, Planning and Design. Eds: Irina Koleva, Ulku Duman Yuksel, Lahcen Benaabidate, St. Kliment Ohridski University Press, ISBN: 978-954-07-4270-0, 409, 2017.

45. CETIN M., SEVIK H. Change of air quality in Kastamonu city in terms of particulate matter and $\mathrm{CO}_{2}$ amount. Oxidation Communications 39, No 4-II, 3394, 2016.

46. CETIN M., SEVIK H. Measuring the Impact of Selected Plants on Indoor $\mathrm{CO}_{2}$ Concentrations. Polish Journal of Environmental Studies, 25 (3), 973, 2016.

47. CETIN M. Chapter 27: Landscape Engineering, Protecting Soil, and Runoff Storm Water, InTech-Open Science-Open Minds, Online July 1st, 2013. Book: Advances in Landscape Architecture-Environmental Sciences, ISBN 978-953-51-1167-2, 697-722, 2013.

48. CETIN M. Chapter 55: Using Recycling Materials for Sustainable Landscape Planning, Environment and Ecology at the Beginning of $21^{\text {st }}$ Century, ST. Kliment 
Ohridski University Press, Sofia, 821 p. ISBN:978-954-073999-1, chapter page: 783, 2015.

49. CETIN M., ZEREN I., SEVIK H., CAKIR C., AKPINAR H. A study on the determination of the natural park's sustainable tourism potential. Environmental Monitoring and Assessment, 190 (3), 167, 2018.

50. CETIN M., ADIGUZEL F., KAYA O., \& SAHAP, A. Mapping of bioclimatic comfort for potential planning using GIS in Aydin. Environment, Development and Sustainability, 20 (1), 361, 2018.

51. CETIN, M. Determination of bioclimatic comfort areas in landscape planning: A case study of Cide Coastline, Turkish Journal of Agriculture-Food Science and Technology, 4 (9), 800, 2016.

52. OMRI A. $\mathrm{CO}_{2}$ Emissions, Energy Consumption and Economic Growth Nexus in MENA Countries: Evidence from Simultaneous Equations Models. Energy Economics, 40, 657. doi:https://doi.org/10.1016/j.eneco.2013.09.003. 2013.

53. FAN Y., LIU L.C., WU G., WEI Y.M. Analyzing impact factors of $\mathrm{CO}_{2}$ emissions using the STIRPAT model. Environmental Impact Assessment Review, 26 (4), 377, 2006.

54. LIN S.F., ZHAO D.T., MARINOVA D. Analysis of the Environmental Impact of China based on STIRPAT
Model. Environmental Impact Assessment Review, 29 (6), 341, 2009.

55. ZHOU W., ZHU B., CHEN D., GRIFFY-BROWN C., MA Y., FEI W. Energy Consumption Patterns in the Process of China's Urbanization. Population and Environment, 33, 202, 2011.

56. ACARAVC A., ERDOGAN S., AKAL G. The electricity consumption, real income, trade openness and FDI: the empirical evidence from Turkey. International Journal of Energy Economics and Policy, 5 (4), 2015.

57. PESARAN M.H., SHIN Y., SMITH R.J. Bounds testing approaches to the analysis of level relationships. J Appl Econ, 16, 289, 2001.

58. RAFIQ S., SALIM, RUHUL, NIELSEN. Ingrid, Urbanization, Openness, Emissions and Energy Intensity: A Study of Increasingly Urbanized Emerging Economies. Energy Economics. doi:10.1016/j.eneco.2016.02.007. 2016.

59. JAMEL L., DERBALI, A. Do energy consumption and economic growth lead to environmental degradation? Evidence from Asian economies. Cogent Economics \& Finance, 4 (1), 117, 2016.

60. COLE M.A., NEUMAYER E. Examining the impact of demographic factors on air pollution. Population and Environment, 26 (1), 5, 2004. 